\title{
Predicting land cover changes and their impact on the sediment influx in the Lake Balaton catchment
}

\author{
Wim Van Dessel · Anton Van Rompaey • \\ Lien Poelmans · Peter Szilassi - Gyozo Jordan • \\ Gabor Csillag
}

Published online: 8 July 2009

(C) Springer Science+Business Media B.V. 2009

\section{Erratum to: Landscape Ecol (2008) 23:645-656 DOI 10.1007/s10980-008-9227-6}

The first author of the paper published in Landscape Ecology (2008) 23:645-656 would like to correct his mistake made in the authorship of the printed paper with sincere apologies. The correct full title of the paper should be referred to as the following:

"Wim Van Dessel, Anton Van Rompaey, Lien Poelmans, Peter Szilassi, Gyozo Jordan, Gabor Csillag: Predicting land cover changes and their impact on the sediment influx in the Lake Balaton catchment."

The online version of the original article can be found under doi:10.1007/s10980-008-9227-6.

W. Van Dessel $(\bowtie) \cdot$ A. Van Rompaey $\cdot$ L. Poelmans Physical and Regional Geography Research Group, K.U. Leuven, Celestijnenlaan 200E, 3001 Heverlee, Belgium e-mail: wim.vandessel@ees.kuleuven.be

P. Szilassi

Department of Geography, Szeged University, Hattyas sor 10, 6725 Szeged, Hungary

G. Jordan

Environmental Geology Department, Geological Institute of Hungary (MAFI), Stefania ut 14, 1143 Budapest,

Hungary

e-mail: jordan@mafi.hu

G. Csillag

Geological Mapping Department, Geological Institute of Hungary (MAFI), Stefania ut 14, 1143 Budapest, Hungary e-mail: csillag@mafi.hu 